This article was downloaded by:[S mithsonian Trpcl Res Inst]

On: 29 May 2007

[S mithsonian Trpcl Res Inst]

Access Details: [subscription number 777121079]

Publisher: Taylor \& Francis

Informa Ltd Registered in England and Wales Registered Number: 1072954

Registered office: Mortimer House, 37-41 Mortimer Street, London W1T 3J H, UK

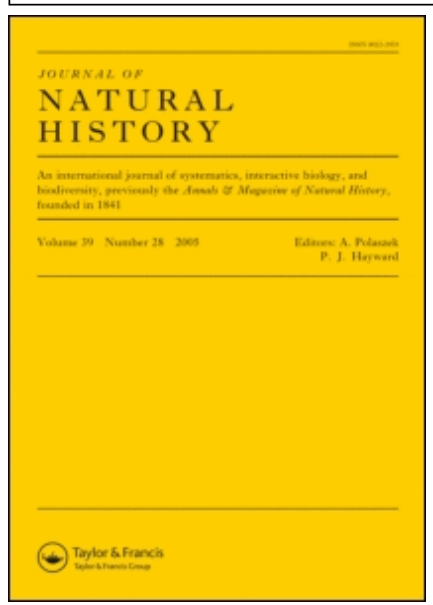

J ournal of Natural History

Publication details, including instructions for authors and subscription information: http://www.informaworld.com/smpp/title $\sim$ content=t713192031

Larval and early juvenile development in Paralomis granulosa (J acquinot) (Decapoda: Anomura: Paguroidea: Lithodidae), with emphasis on abdominal changes in megalopal and crab stages

P. A. MCLAUGHLIN ${ }^{a}$; K. Anger ${ }^{b}$; A. Kaffenberger ${ }^{b} ;$ G. A. Lovrich ${ }^{c}$

${ }^{a}$ Shannon Point Marine Center, Western Washington University, 1900 Shannon

Point Road, Anacortes, WA 98221-9081B, USA; e-mail: patsy@ sos.net.

${ }^{b}$ Alfred-Wegener-Institut für Polar- und Meeresforschung: Biologische Anstalt

Helgoland, Meeresstation, D-27498 Helgoland, Germany.

${ }^{c}$ Centro Austral de Investigaciones Cientificas (CADIC-CONICET), CC 92, (9410)

Ushuaia, Tierra del Fuego, Argentina.

To cite this Article: McLAUGHLIN, P. A., Anger, K., Kaffenberger, A. and Lovrich, G. A. , 'Larval and early juvenile development in Paralomis granulosa (J acquinot) (Decapoda: Anomura: Paguroidea: Lithodidae), with emphasis on abdominal changes in megalopal and crab stages', J ournal of Natural History, 37:12, 1433 - 1452

To link to this article: DOI: $10.1080 / 00222930110109073$

URL: http://dx.doi.org/10.1080/00222930110109073

PLEASE SCROLL DOWN FOR ARTICLE

Full terms and conditions of use: http://www.informaworld.com/terms-and-conditions-of-access.pdf

This article maybe used for research, teaching and private study purposes. Any substantial or systematic reproduction, re-distribution, re-selling, loan or sub-licensing, systematic supply or distribution in any form to anyone is expressly forbidden.

The publisher does not give any warranty express or implied or make any representation that the contents will be complete or accurate or up to date. The accuracy of any instructions, formulae and drug doses should be independently verified with primary sources. The publisher shall not be liable for any loss, actions, claims, proceedings, demand or costs or damages whatsoever or howsoever caused arising directly or indirectly in connection with or arising out of the use of this material.

(c) Taylor and Francis 2007 


\title{
Larval and early juvenile development in Paralomis granulosa (Jacquinot) (Decapoda: Anomura: Paguroidea: Lithodidae), with emphasis on abdominal changes in megalopal and crab stages
}

\author{
P. A. McLAUGHLIN $\dagger$, K. ANGER + , A. KAFFENBERGER + and \\ G. A. LOVRICH§ \\ $\dagger$ Shannon Point Marine Center, Western Washington University, \\ 1900 Shannon Point Road, Anacortes, WA 98221-9081B, USA; \\ e-mail: patsy@sos.net \\ $\$$ Alfred-Wegener-Institut für Polar- und Meeresforschung: Biologische \\ Anstalt Helgoland, Meeresstation, D-27498 Helgoland, Germany \\ $\S$ Centro Austral de Investigaciones Cientificas (CADIC-CONICET), \\ CC 92, (9410) Ushuaia, Tierra del Fuego, Argentina
}

(Accepted 15 October 2001)

\begin{abstract}
Morphological variations in the two zoeal stages and megalopa of a lecithotrophic population of Paralomis granulosa (Jacquinot) reared under laboratory conditions are reviewed. Attention is also directed to certain aspects of their development not previously considered. More importantly, the first three juvenile stages are described and illustrated for the first time. Specific consideration is given to the structural changes in the abdominal tergites during the transformation from megalopa to third crab, and ancillary information on abdominal plate development in juvenile stages four and five is provided. Total pleopod loss in both sexes and subsequent reappearance in females is discussed.
\end{abstract}

Keywords: Crustacea, Anomura, Lithodidae, Paralomis, larval and juvenile development.

\section{Introduction}

Larval development in the genus Paralomis consists, as far as is known, of two zoeal stages and a megalopal stage. Of the 46 species assigned to this genus, zoeal and megalopal stages have been described only for Paralomis granulosa (Jacquinot in Hombron and Jacquinot, 1846), by Campodonico and Guzmán (1981), for $P$. japonicus Balss, 1911, by Hayashi and Yanagisawa (1985), and for P. hystrix (De Haan, 1846), by Konishi and Taishaku (1994). Heretofore, no morphological information has been available for the early crab stages. In addition to describing and illustrating the structural attributes of the first three crab stages of Paralomis granulosa, we have paid particular attention to the changes occurring in the abdominal tergites between the megalopal and the early crab stages and to juvenile

\footnotetext{
Journal of Natural History

ISSN 0022-2933 print/ISSN 1464-5262 online (C) 2003 Taylor \& Francis Ltd

http://www.tandf.co.uk/journals

DOI: $10.1080 / 00222930110109073$
} 
pleopod loss. However, we also have had the opportunity to note some variations in the zoeal morphology from that reported by Campodonico and Guzmán (1981) for a population at Puerto Zenteno, Straits of Magellan. Variations observed in the structures of mandibles and maxillules may, at least in part, be correlated with the fact that larvae from our more southern population of $P$. granulosa are fully lecithotrophic, at least during the zoeal stages (Kaffenberger, 2001). Additionally, since the completion of the initial study, supplemental information on abdominal plate development has been become available from surviving juveniles that moulted to crab stages four and five.

\section{Materials and methods}

Females of Paralomis granulosa were collected in Beagle Channel, near Ushuaia, Tierra del Fuego, Argentina, and transported to the Helgoland laboratory aboard the RV Polarstern. These females were held in live tanks with running seawater $\left(6^{\circ} \mathrm{C}\right.$, $32 \%$ salinity) until their larvae hatched. The larvae were provided with filtered ( $1 \mu \mathrm{m}$ pore size) North Sea water at constant $6^{\circ} \mathrm{C}$, a salinity of $32 \%$, and artificial light conditions with 12:12 h light: darkness. Sibling larvae were individually reared in 100-ml beakers under fed (freshly hatched Artemia franciscana; food density ca 10 nauplii per $\mathrm{ml}$ ) and non-fed conditions. Water was changed every 2 days. Larval development from hatching through metamorphosis to the first juvenile crab instar was at least facultatively lecithotrophic; no significant differences between the two treatments occurred in the duration of development or in the rate of mortality; details of larval and early juvenile development, growth and changes in chemical composition will be published elsewhere. Samples for the morphological examination were taken from unfed cultures.

Five individuals from each zoeal, megalopal and first crab, two from the second and five from the third crab stages were preserved in $70 \%$ ethyl alcohol for morphological examination. Supplemental information on the second and third crab stages were obtained through the examination of exuviae. Additionally, five individuals and three exuviae of the fourth crab stage and five individuals of the fifth crab stage were reviewed for abdominal plate development. Specimens were stained in $1 \%$ chorazol black $\mathrm{E}$ for detailed examination. Zoeas were initially evaluated using a Wild M-5 dissecting microscope, then dissected and mounted in polyvinyl alcohol lactophenol and critically examined using a Wild M-20 compound microscope. Megalopal and early crab stage specimens were dissected in 70\% ethyl alcohol, with non-calcareous appendages also mounted in polyvinyl alcohol lactophenol. All illustrations were made with the aid of camera lucidas mounted on these microscopes. One measurement, carapace length $(\mathrm{cl})$, as measured from the tip of the anterior rostral projection to the mid-point of the posterior carapace, provides an indication of animal size. Terminology for the descriptions follows that of Crain and McLaughlin (2000a).

\section{Developmental descriptions}

First zoeal stage $(\mathrm{cl}=2.75-3.25 \mathrm{~mm} ; \mathrm{N}=5)$

Campodonico and Guzmán (1981) reported that the eyes of their first-stage zoeas were sessile. While anomuran eyes are sessile in typical Zoea I larvae (Fincham, 1992), Crain and McLaughlin (2000a) noted that the eyes in the lithodid, Lopholithodes mandtii Brandt, 1848, which has four, or rarely five zoeal stages, 
varied from being partially fused to the carapace to being completely stalked. The eyes in our specimens of Paralomis granulosa (figure 1A) all are stalked, although the peduncles remain adjacent to the orbital walls of the carapace. The ocular peduncles each consists of a single 'segment' (cf. Powar, 1969), with delineated cornea.

Although development of the protopodal spines of the antenna and setation of the scaphocerite in our specimens (figure 2C) are comparable, the endopod lacks any trace of the incipient segmentation described and illustrated by Campodonico and Guzmán (1981: figure 1F) for their first-stage zoeas. A feature not mentioned by these authors in their description of the antenna is the prominence of the protrusion marking the orifice of the antennal gland that is present in our specimens.

Campodonico and Guzmán described the mandible as being strong, with a series of small teeth. In our sample, the mandibles (figure $2 \mathrm{E}$ ) lack all traces of calcification. Although incisor and much-reduced molar processes are distinguishable, dentition on the incisor process consists of one prominent tooth, and a series of minute denticles; only a few very miniscule denticles can be seen on the molar process. A small, unsegmented palp bud is present.
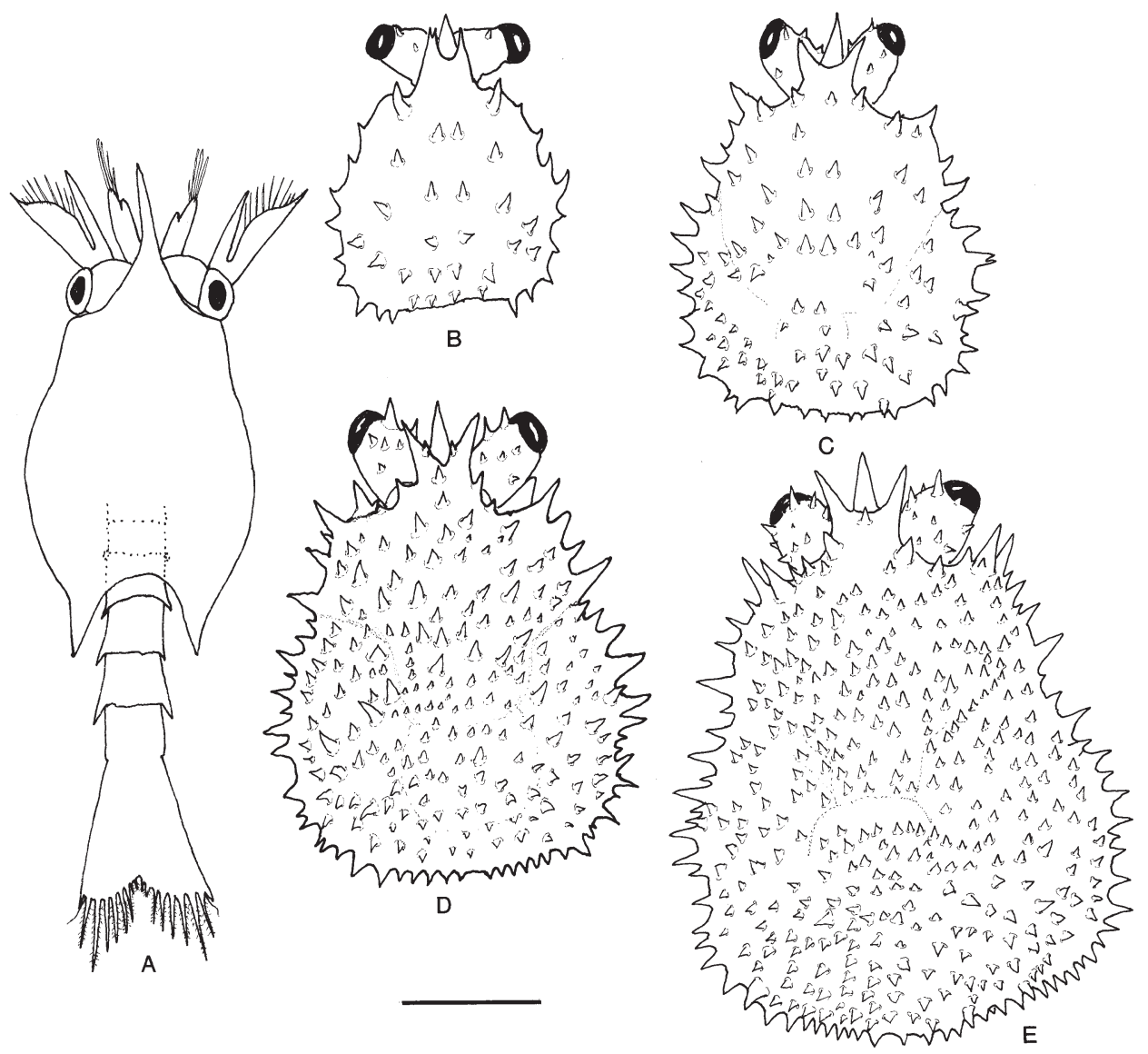

FIG. 1. Paralomis granulosa (Jacquinot, 1846). (A) Whole animal (dorsal view); (B-E) carapace and ocular peduncles (dorsal view). (A) First zoeal stage; (B) megalopa; (C) first crab stage; (D) second crab stage; (E) third crab stage. Scale $=1 \mathrm{~mm}$. 


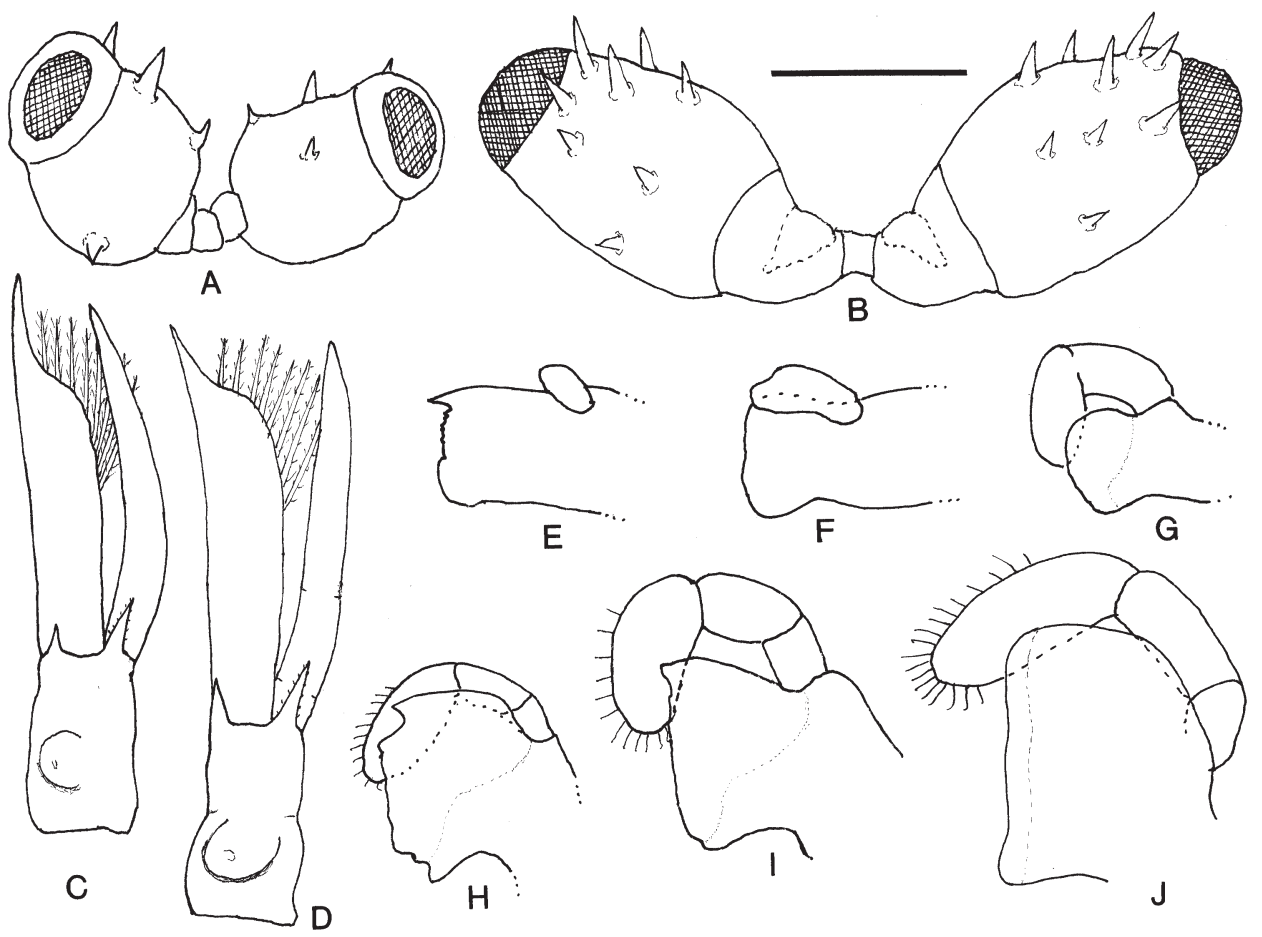

Fig. 2. Paralomis granulosa (Jacquinot, 1846). (A, B) Ocular peduncles (dorsal view); (C, D) antennae (ventromesial view); (E-J) mandible (left, external view). (A) Megalopa; (B) crab stage 3; (C), first zoeal stage; (D) second zoeal stage; (E) first zoeal stage; (F) second zoeal stage; $(\mathrm{G})$ megalopa; $(\mathrm{H})$ first crab stage; (I) second crab stage; $(\mathrm{J})$ third crab stage. Scale $=0.5 \mathrm{~mm}(\mathrm{~A}, \mathrm{~B}), 0.4 \mathrm{~mm}(\mathrm{C}, \mathrm{D})$ and $0.25(\mathrm{E}-\mathrm{J})$.

The endopod of the maxillule (figure 3A) is three-segmented in our specimens rather than two-segmented, as reported by Campodonico and Guzmán; only one or two short terminal setae are present. In both populations, the basial endite of this appendage has two quite small, weakly denticulate teeth. Development of the coxal endite appears similar.

In our specimens, the proximal lobe of the scaphognathite of the maxilla (figure $3 \mathrm{E}$ ) is not delineated, whereas this lobe is described as forming a pointed lobe in Campodonico and Guzmán's specimens. Our specimens also had fewer setae on the distal lobe. Similarly, the endopod and both lobes of the coxal and basial endites are provided with fewer setae in our material.

Konishi and Taishaku (1994) reported 'regressive' mouthpart morphology for Paralomis hystrix, and suggested that the main mouthparts might not be functional during the zoeal stages. The reductions in the mouthparts, particularly in the mandibles and maxillules, observed in our population of $P$. granulos $a$ are consistent with their full lecithotrophy. When viewed in situ, the mandibles and maxillules of all our specimens are not only markedly reduced but widely separated by the labrum and paragnaths. This is in significant contrast to the structure and position of these appendages as described and illustrated by Crain (1999) for Placetron wosnessenskii Schalfeew, 1892 first-stage zoeas, which are known to feed actively.

Gills were not mentioned by Campodnico and Guzmán (1981); however, in all 


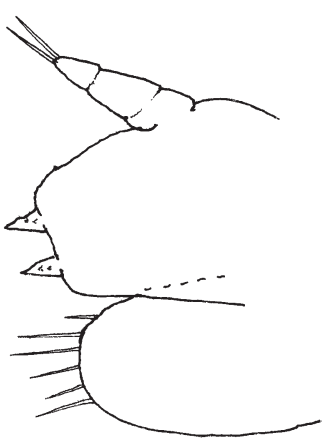

A

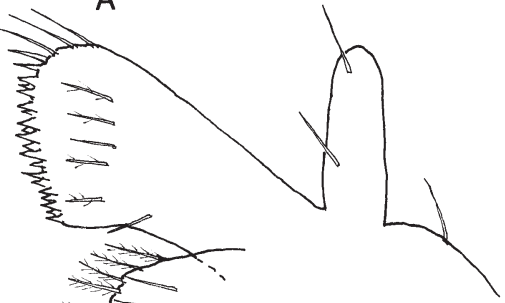

?

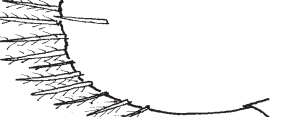

D
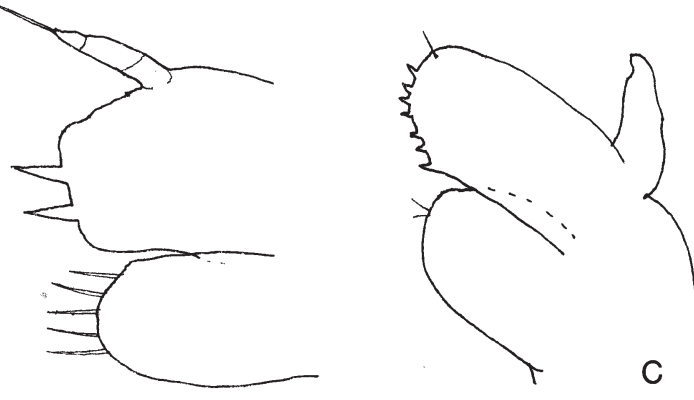

B

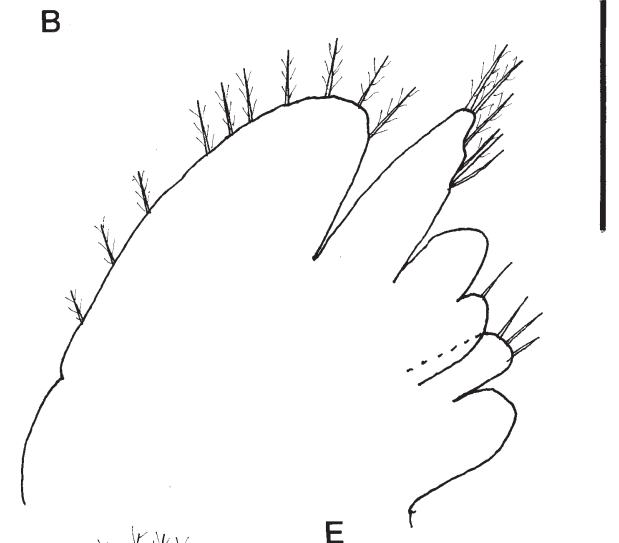

$E$
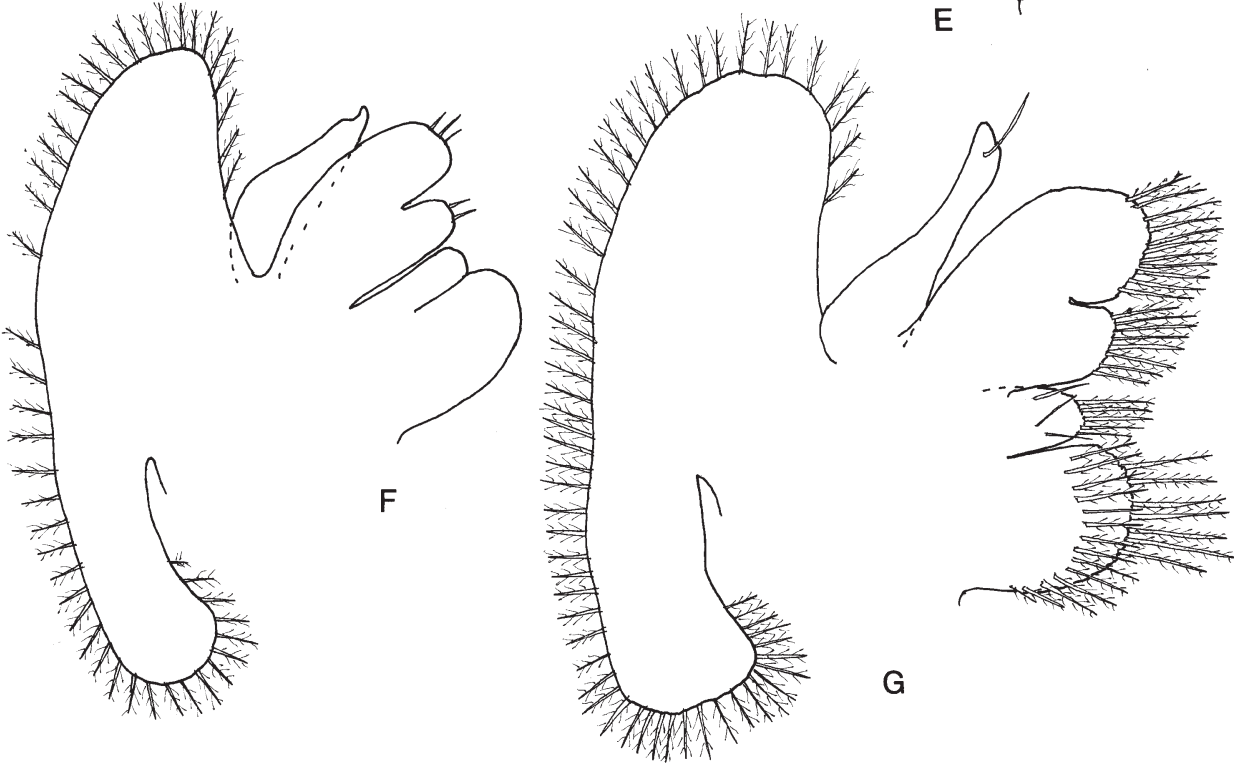

FIG. 3. Paralomis granulosa (Jacquinot, 1846). (A-D) Maxillule (left, external view); (E-G) maxilla (right, external view). (A) First zoeal stage; (B) second zoeal stage; (C) megalopa; (D) first crab stage; (E) first zoeal stage; (F) megalopa; (G) first crab stage. Scale $=0.25 \mathrm{~mm}$. 
of our first-stage zoeas arthrobranchial buds were present at the bases of the developing chelipeds and ambulatory legs.

Campodonico and Guzmán described abdominal somites 2-5 as each bearing a pair of strong lateral spines, usually an additional two to four spines on the posterodorsal margins, and a pair of dorsal hair-like setae. In our specimens (figure 1A) the posterodorsal margins exhibit nothing more than weak crenulations or minute protuberances; no dorsal hair-like setae have been observed. Paired abdominal pleopods 2-5 were described by the earlier authors as present, with rudimentary endopods developed. In three of our five specimens, the pleopods are represented only by incipient, uniramous buds. In the other two, uniramous, but moderately well-developed pleopod buds are present. The telson, while not distinctly separated from the sixth somite, does show indications of potential separation. No anal spine has been observed in any of our material.

Second zoeal stage ( $\mathrm{cl}=2.87-3.22 \mathrm{~mm} ; \mathrm{N}=5)$

Campodonico and Guzmán (1981) gave no measurements for their specimens, but judging from their illustrations (1981: figures 1A, B, 2A, B), their specimens, like ours, showed no noticeable growth from the first stage to the second. Variations in the second-stage development of zoeas from the two populations includes segmentation of the antennules and antennae, and differences in the mandibles and maxillules.

The incipient segmentation of neither the antennular peduncle nor its endopod and exopod is as advanced in our second-stage zoeas as described by Campodonico and Guzmán. The peduncle in our specimens shows only slight indications of division into two segments, as does the exopod. No impending segmentation of the endopod can be detected.

Only two or three incipient segments have been observed on the endopod of the antenna (figure 2D); however, the first segment of the peduncle shows partial delineation and the protrusion of the antennal gland is more prominent than in the preceding stage.

The molar process of the mandible (figure $2 \mathrm{~F}$ ) is no longer distinguishable in the present material, although both processes are illustrated by Campodonico and Guzmán (1981: figure 2G). The mandibular palp has enlarged in our specimens, but no incipient segmentation is detectable.

Like the maxillules in the earlier study, the coxal endite has only a few short setae, and the basial endite has only two small spine-like teeth. However, while Campodonico and Guzmán illustrate a still two-segmented endopod with three terminal setae, the endopods of our specimens are three-segmented, but with only a single terminal seta (figure 3B).

The proximal lobe of the scaphognathite is now separated from the protopod; however, setation is not as abundant as indicated by Campodonico and Guzmán for their specimens.

Arthrobranchs are better developed at bases of the chelipeds and ambulatory legs.

Well-developed, unequally biramous pleopod buds are now present on abdominal somites 2-5; however there is no indication of setae. As in Campodonico and Guzmán's population, there is still nothing more than a faint hint of separation of the telson and sixth somite. No uropods are developed. 
Megalopa $(\mathrm{cl}=2.06-2.18 \mathrm{~mm} ; \mathrm{N}=5)$

The carapace lengths of the megalopas of the two populations are practically identical. Development of the anterior process (rostral spine of Campodnico and Guzmán) and carapace spines (figure 1B) is also quite similar in the two populations, although it is more variable in ours. In our specimens, the dorsal rostral spines (anterolateral spines of Campodonico and Guzmán) are simple or bifid, and nearly as long as the anterior process The linea anomurica is only weakly delineated anteriorly at the carapace margin.

Segmentation of the ocular peduncles was not addressed by Campodonico and Guzmán. In our specimens, the ocular peduncles (figure 2A) at this stage are clearly three-segmented, the third (distal) and second (subdistal) segments are separated by a median ocular plate, representing the fused first (proximal) segments. Each distal peduncular segment is provided with three or four spines, as it is in Campodonico and Guzmán's specimens.

Development in the megalopal antennule (figure 4A) is comparable between the

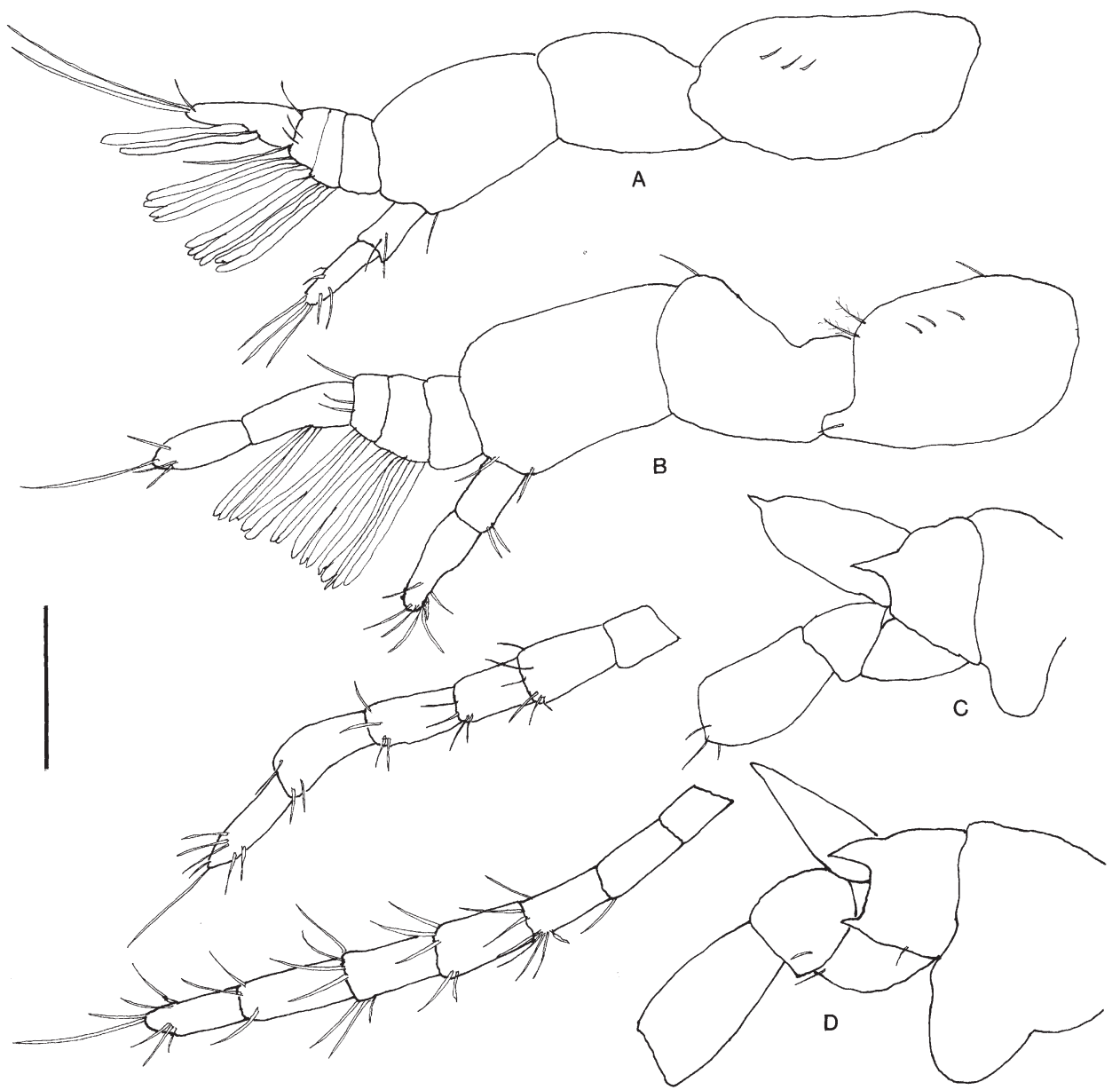

FIG. 4. Paralomis granulosa (Jacquinot, 1846). (A, B) Antennule (lateral view); C, D, antennal peduncle (lateral view) and flagellum (detached). (A) Megalopa; (B) first crab stage; (C) megalopa; (D) first crab stage. Scale $=0.25 \mathrm{~mm}$. 
two populations, although the second article of the upper ramus has six to eight aesthetascs rather than the four reported by Campodonico and Guzmán. Differences in terminology are attributed, in part, to the apparent variation seen in the antenna (figure 4C). Campodonico and Guzmán (1981: 279, figure 3F) refer to the three distal segments of the antennal peduncle and the antennal flagellum collectively as the endopod; the first and second peduncular segments are reported as the 'basal peduncle'. In our specimens, the antennal flagellum consists of six articles, which is consistent with the flagellar portion of the earlier authors' 'endopod'. Only one of the 'two short ventral spines' of their 'basal peduncle' is present in our examples, and that spine is on the dorsolateral distal angle of the second peduncular segment. A supernumerary segment is apparent above the third segment.

Some variation is discernible in the feeding appendages, which now include the three maxillipeds. Only the palp of the mandible is described by Campodonico and Guzmán, and they report that it is well developed and three-segmented. They do, however, illustrate the mandible (1981: figure $3 \mathrm{G}$ ) as having a denticulate medial margin. The mandibular palp in our specimens is moderately well developed, but only two-segmented and lacking all setae. The mandible (figure $2 \mathrm{G}$ ) has a smooth, unarmed medial margin or may have one or two miniscule denticles, the exterior surface is similarly smooth; however, the inner surface is deeply concave and partially divided by a ridge that might be interpreted as a vestige of the molar process.

The maxillule is again reported by Campodonico and Guzmán to have a twosegmented endopod; the basial endite (their basipodite) bears three or four setae and several small teeth; the coxal endite (their coxopodite) is provided with two or three setae and a few lateral teeth. In contrast, the maxillules (figure 3C) of our specimens have an unsegmented, naked endopod. The basial endite is provided with seven to ten marginal small teeth and one or two submarginal short setae; the coxal endite has only two to four very short setae.

The megalopal maxillas (figure 3F) in our material, like their zoeal counterparts, lack much of the setation of the coxal and basial lobes described by Campodonico and Guzmán for their specimens. However, the scaphognathites in our sample have 42-47 marginal setae. The earlier authors recorded from 45 to 54 setae.

The primary differences seen in the maxillipeds between the two populations is in the setation of the first and the segmentation of the third. Whereas the coxal and basial endites of the first maxilliped (figure 5A) are provided with marginal setae in Campodonico and Guzmán's megalopas, these endites completely lack setae or at most have only one or two extremely short setae in our sample. The earlier authors also report that the endopod of the third maxilliped is four-segmented, and illustrate (Campodonico and Guzmán, 1981: figure 3L) a large basal protuberance on the protopod. Our specimens have five-segmented endopods (figure 5D) and completely lack any unusual protuberance on the protopod. There is a slight indication of the developing crista dentata that was not mentioned for their population, and a strong spine is present on the ventromesial distal surface of the ischium in our specimens.

As in the earlier study, the megalopal chelipeds and ambulatory legs all are provided with slender, acute spines. The fifth pereopod is reduced and already carried under the carapace. A pair of small arthrobranchs are now present at bases of the third maxillipeds; larger and better-developed arthrobranchs are seen at bases of chelipeds and ambulatory legs; a pleurobranch bud is present on the thoracic wall above the fourth pereopod.

There is a certain amount of disagreement in the armature of the abdominal 


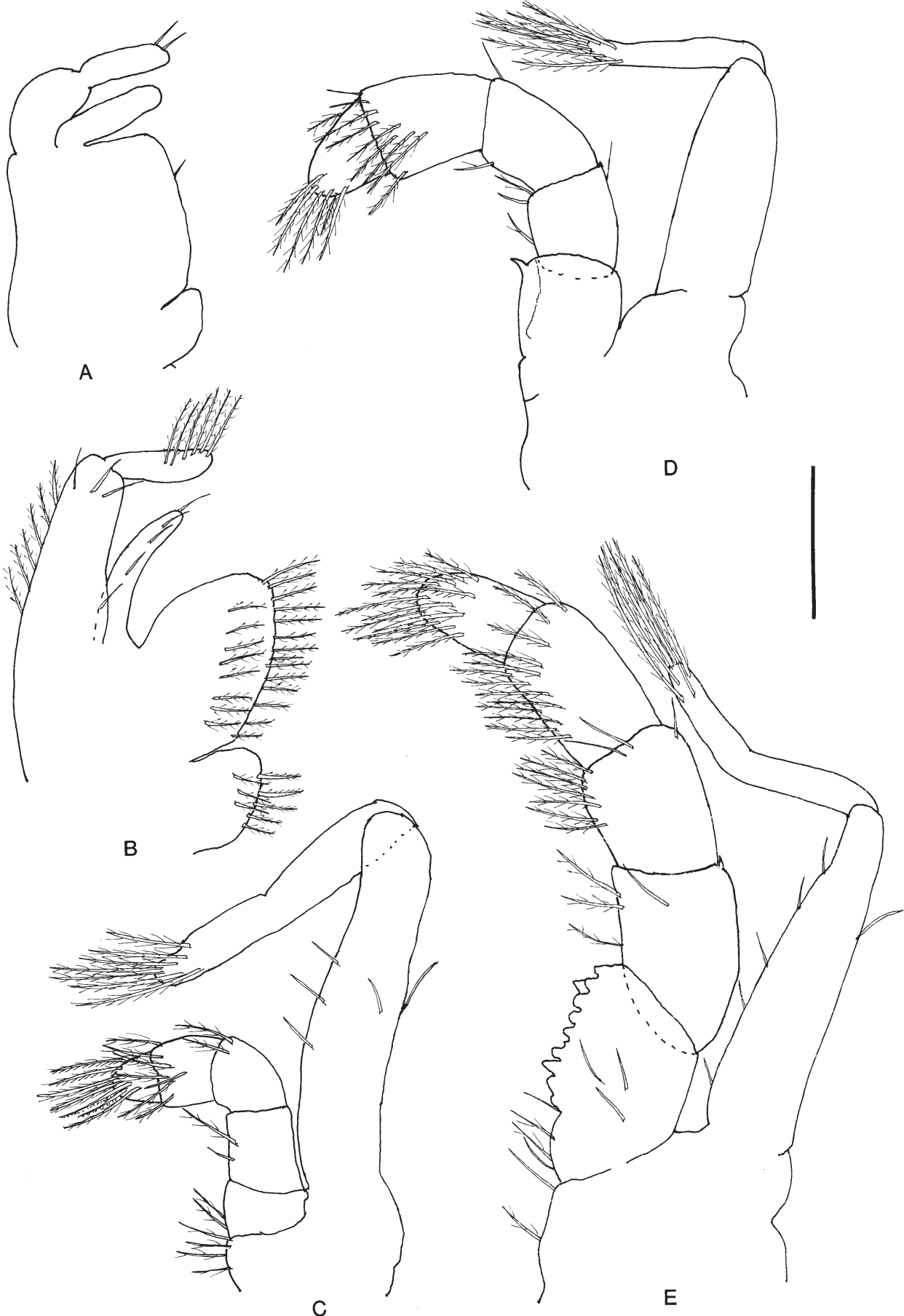

FIG. 5. Paralomis granulosa (Jacquinot, 1846). (A, B) First maxilliped (right, external view); (C) second maxilliped (left, external view); (D, E) third maxilliped (left, external view). (A) Megalopa; (B) first crab stage; (C) first crab stage; (D) megalopa; (E) first crab stage. Scale $=0.25 \mathrm{~mm}$. 
tergites in Campodonico and Guzmán's megalopas and ours. These same tergal spines generally can be traced in the elements of the tergites in subsequent crab stages. All megalopal tergites (figure 6A) are well calcified. The first is appreciably smaller than the second and armed with a pair of prominent, median, dorsal spines and a smaller pair of spines dorsolaterally. The tergite of the second somite is broad, convex, and armed with an anterodorsal row of four spines, the median pair being appreciably larger than the lateral pair, a posterodorsal row of four spines, and a

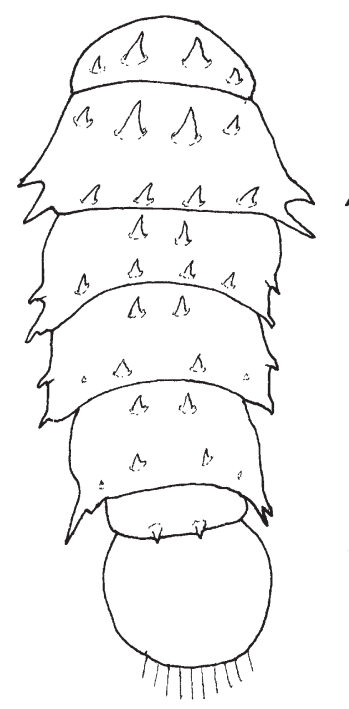

A
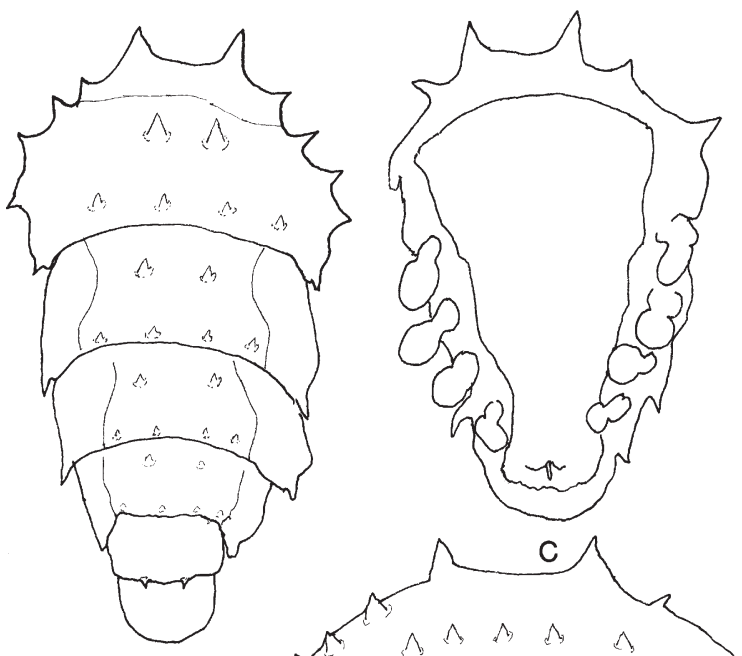

B

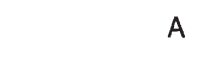

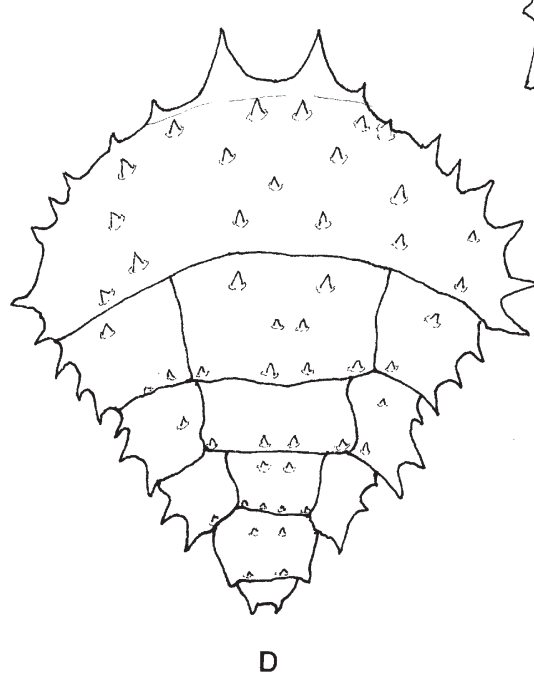

D

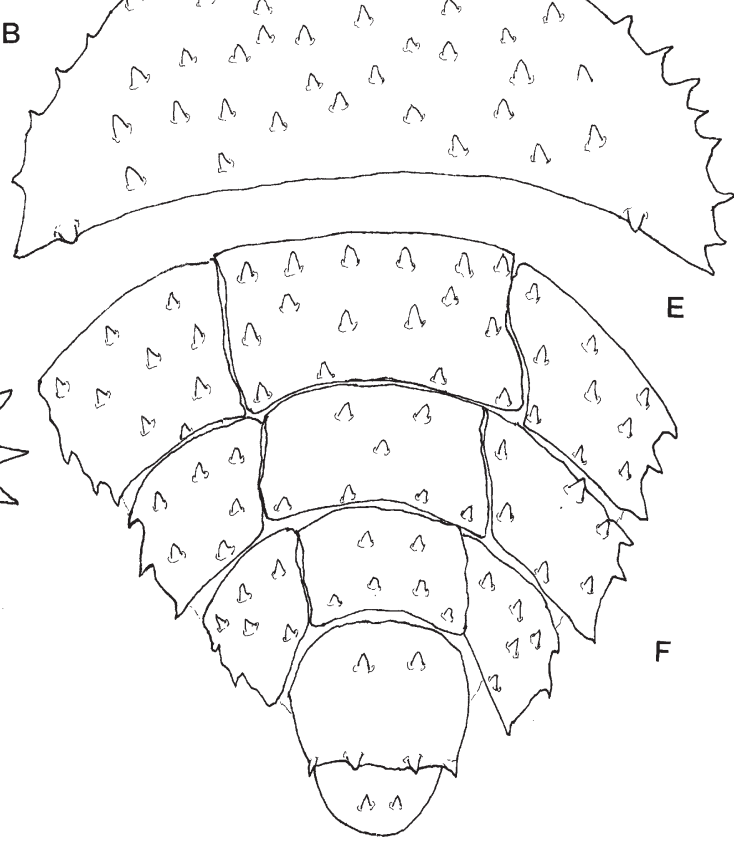

FIG. 6. Paralomis granulosa (Jacquinot, 1846). (A, B, D-F) Abdomen (dorsal view); (C) abdomen (ventral view). (A) Megalopa; (B) first crab stage; (C) first crab stage; (D) second crab stage; (E) third crab stage fused first and second tergites; (F) third crab stage tergites 3-6 and telson. Scale $=0.5 \mathrm{~mm}$. 
pair of simple or bifid spines on each lateral surface, strongest at the posterior angle. The tergites of the third to fifth somites are each slightly narrower than the preceding; each is armed with a pair of anterodorsal spines and a row of four posterodorsal spines; the lateral pair of this row often are tiny, and sometimes represented only by slight protuberances. Paired lateral spines are present on these somites; those at the posterolateral angles are larger and increase in size distally, whereas the more anterior spines decrease in size distally, and may even be lacking on the fifth tergite. The tergite of the sixth somite, now clearly delimited, is armed with a small pair of posteromedian spines. Frequently, each tergal spine is accompanied by a single seta. The telson is roundly subquadrate and provided with setae on the rounded or slightly indented terminal margin.

First crab stage $(\mathrm{cl}=2.42-2.87 \mathrm{~mm} ; \mathrm{N}=5)$

Carapace (figure 1C). Elongate and roundly subrectangular in outline, globular; with gastric and cardiac regions faintly delineated, spines varying in strength and number; anterior projection moderately long, basally moderately narrow to moderately broad, terminally acute and slightly curved upward, dorsal spines prominent, simple or bifid, dorsal and ventral rostral surfaces unarmed; external orbital and antero-external spines small to large, hepatic spine prominent; gastric region with two or three pairs of small to moderately large spines medianly and few to several additional small spines laterally; cardiac region with three or four pairs of small to moderately large median spines and few to several smaller spines laterally; branchial regions each with several small and few larger, simple and bifid spines; marginal carapace spines numerous, prominent and frequently bifid. Ocular peduncles with distal peduncular segments each with four to six spines. Linea anomurica now clearly delineating branchostegial portion of carapace.

Antennule (figure 4B). Basal peduncular segment with three to several short setae on upper margin of statocyst lobe, one or two plumose setae distally; one to four short setae distally on penultimate segment; distal segment with one or two short setae ventrally; upper ramus of flagellum with five articles, groups of $0,6-8,4-6,4$ aesthetascs, progressing distally, distal article with one long terminal seta and two to four shorter setae subterminally, often one moderately long seta in proximal half; lower ramus still with two articles, basal article usually with two or three short setae distally, distal article with four to six subterminal and two or three terminal setae.

Antenna (figure 4D). Peduncle with well-developed spine at dorsolateral distal angle of segment second and smaller spine at dorsomesial distal angle; scaphocerite subtriangular, with acute terminal spine-like projection; flagellum with seven distinct articles, setal formula progressing distally, $0,0-1,2-8,2-5,2-7,2-3,4-7$ terminal and/or subterminal.

Mandible (figure $2 \mathrm{H}$ ). Well calcified; incisor process with few blunt to subacute small teeth on medial margin; remnant of molar process appearing as one large blunt tooth basally, inner surface with lower half developed as prominent ridge; palp indistinctly three-segmented, terminal segment with 10-12 short setae.

Maxillule (figure 3D). Coxal endite 14-18 marginal and two or three submarginal plumose or plumodenticulate setae; basial endite with double row of spiniform, cuspidate setae and 9-12 marginal and submarginal, simple and plumose setae; endopod with one terminal and one proximal seta.

Maxilla (figure 3G). Proximal lobe of coxal endite with marginal row of 9-18 plumose and plumodenticulate setae, and submarginal row of 12-14 simple or 
plumose setae; distal lobe with one to four submarginal and five to seven marginal plumose or plumodenticulate setae; basial endite with 3-12 marginal plumose setae on proximal lobe, 1-14 marginal and no to three submarginal plumose setae on distal lobe; endopod with one subterminal seta; scaphognathite with 55-63 marginal plumose setae.

First maxilliped (figure 5B). Coxal endite with 7-10 marginal or submarginal plumose setae; basial endite 14-18 marginal plumose and plumodenticulate setae and 8-10 submarginal plumose setae; endopod unsegmented, with three or four setae; exopod two-segmented, with six marginal and four or five surface, simple or plumose setae on proximal segment, six apical, plumose setae on distal segment.

Second maxilliped (figure 5C). Endopod five-segmented, segments all with some marginal plumose setae, fewest proximally, also plumodenticulate setae on propodus and dactyl; exopod two-segmented, with three or four short setae on inner and one seta on outer margin of proximal segment, distal segment with six to eight apical, plumose setae.

Third maxilliped (figure 5E). Endopod with crista dentata now clearly developing, with seven or eight small teeth, accessory tooth apparent; carpus with few denticulate, simple and plumose setae; propodus with some plumose and numerous serrate and/or denticulate setae; exopod with six to eight plumose, apical setae.

Pereopods (figure 7A-D). Chelipeds subequal, dactyls and fixed fingers with few

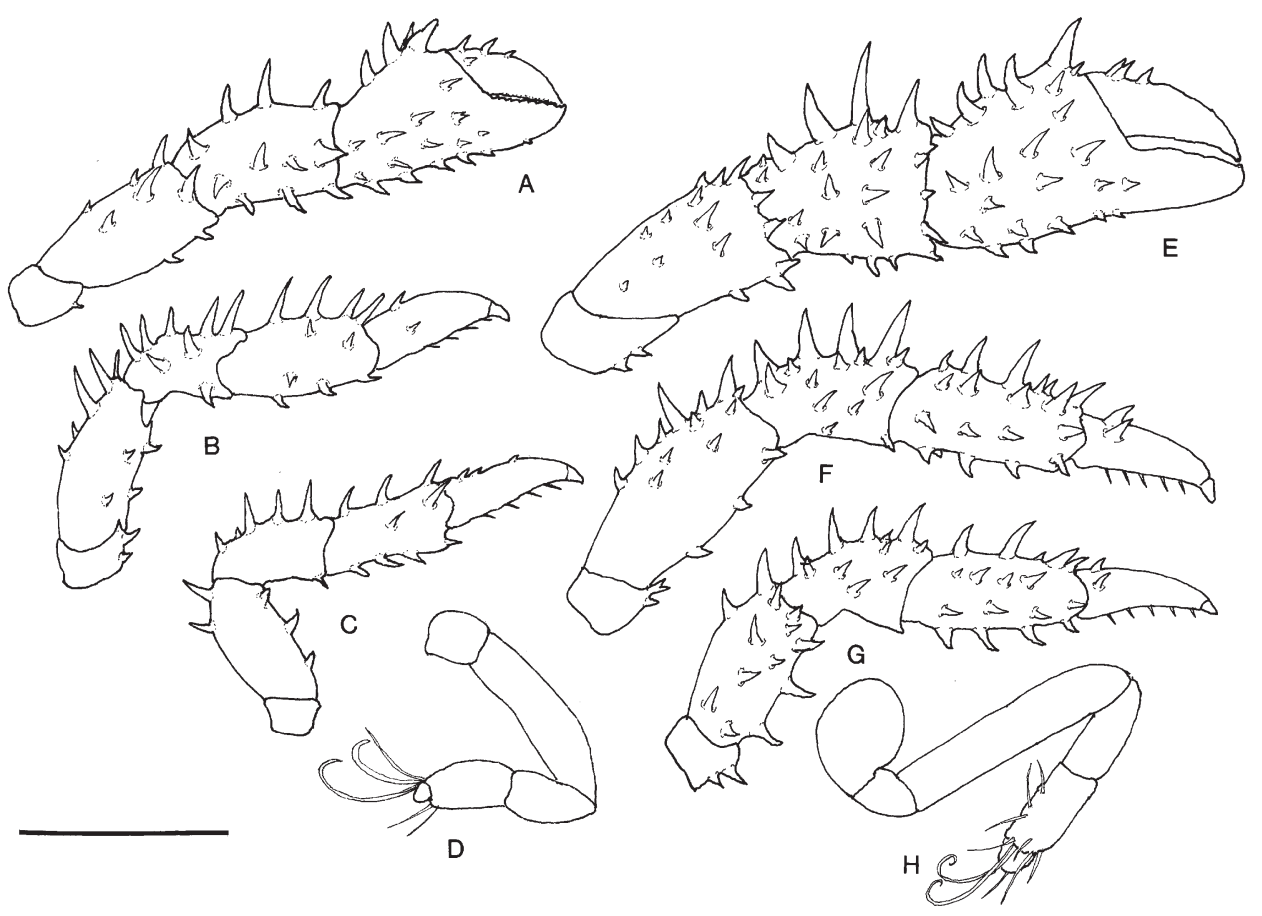

Fig. 7. Paralomis granulosa (Jacquinot, 1846). (A-D) Crab stage 1; (E-H) crab stage 2. (A) Right cheliped (dorsal view); (B) right second pereopod (lateral view); (C) right fourth pereopod (lateral view); (D) right fifth pereopod (lateral view); (E) right cheliped (dorsal view); (F) right second pereopod (lateral view); $(\mathrm{G})$ right fourth pereopod (lateral view); $(\mathrm{H})$ right fifth pereopod (lateral view). Scale $=1 \mathrm{~mm}(\mathrm{~A}-\mathrm{C}$, $\mathrm{E}-\mathrm{G})$ and $0.5 \mathrm{~mm}(\mathrm{D}, \mathrm{H})$. 
short to moderately long spines; palms, carpi, meri, all with numerous long, slender, usually acute, and often corneous-tipped spines. Ambulatory legs as long or longer than chelipeds, first (second pereopod) longest; dactyls each with row of four or five corneous spines on ventral margin; propodi, carpi and meri all with numerous long, slender, acute spines. Fifth pereopods reduced, carried beneath carapace. Paired biserial arthrobranchs with well-differentiated lamellae on bases of third maxillipeds, chelipeds and pereopods 2-4; equally well-developed pleurobranch on thoracic wall above fourth pereopod.

Abdomen (figure 6B, C). Strongly flexed against cephalothorax; first and second somites with tergal plates entire, distinct or partially to almost entirely fused; four large spines of first still very prominent, or with lateral pair markedly reduced; second still with both anterodorsal and posterodorsal row of four spines, additional one or two pairs of spines on each lateral margin; third to fifth somites each with incomplete or complete lateral sutures dividing tergites into median and lateral plates, median plates each still with pair of anterodorsal spines and row of four posterodorsal smaller spines; lateral plates each sometimes with additional one to three marginal or submarginal spines, largest at posterolateral angle; sixth somite with tergite entire, armed with pair of spines on posterodorsal margin.

Pleopods (figure 6C). Varying from still present, but rudimentary, with left slightly larger than right, to entirely absent on both sides.

Telson. Subcircular to laterally subovate, unarmed.

Second crab stage ( $\mathrm{cl}=2.60-3.26 \mathrm{~mm} ; \mathrm{N}=9$ )

Carapace (figure 1D). Roundly subtriangular; dorsal spines of rostrum somewhat smaller but still prominent, and sometimes with one or two accessory spinules, terminally simple or weakly bifid; external orbital and antero-external spines reduced; gastric region sometimes with pair of somewhat larger median spines and two additional pairs of moderately large spines distinguishable, sometimes only with numerous small spines; cardiac region also with numerous small spines, frequently two slightly larger median pairs; branchial regions with numerous smaller spines and often one larger pair posteriorly. Ocular peduncles with second segment somewhat larger than in previous stage; distal segment usually with one or two additional spines.

Antennule. Two to four additional aesthetases and two or three additional setae on upper ramus; lower ramus usually incompletely three-segmented.

Antenna. Scaphocerite more prominently produced, margins occasionally microscopically serrate; flagellum with seven or eight articles.

Mandible (figure 2I). Medial margin smooth or with few minute denticles, inner surface with broad thick shelf in lower half; palp still with 10-12 short marginal setae.

Maxillule. Little changed from previous stage.

Maxilla. Proximal lobe of coxal endite with marginal row of 12-16 plumose and/or plumodenticulate setae, and submarginal row of 10 or 11 weakly plumose setae; distal lobe with five to seven submarginal and four to six marginal plumose or plumodenticulate setae; basial endite usually with one submarginal and five to seven marginal plumose setae on proximal lobe, one submarginal and 12-14 marginal plumose setae on distal lobe; endopod still with one subterminal seta; scaphognathite with 56-62 marginal plumose setae.

First maxilliped. Coxal endite with 7-10 marginal or submarginal plumose setae; basial endite with 15-18 marginal plumose and plumodenticulate setae and seven 
to nine submarginal plumose setae; endopod with one or two subterminal and four to seven surface plumose or simple setae; exopod with six simple, marginal and four simple or plumose, surface setae on proximal segment, six apical setae on distal segment. Second and third maxillipeds with endopod setation slightly increased.

Pereopods. Chelipeds and ambulatory legs all with increased length and spination.

Abdomen (figure 6D). Symmetrically subtriangular; tergite of somite 1 usually partially to completely fused with tergite of somite 2 ; lateral plates of tergites 3-5 entirely separated from median plates.

Pleopods. Completely absent.

Telson. Roundly subquadrate; pair of small terminal spines developing.

Third crab stage ( $\mathrm{cl}=3.26-3.92 \mathrm{~mm} ; \mathrm{N}=9)$

Carapace (figure 1E). Still roundly subtriangular; dorsal spines of rostrum still prominent, with simple or weakly bifid tips; external orbital and antero-external spines as in previous stage; gastric region with numerous moderate to small spines; cardiac and branchial regions also with increased number of small spines. Ocular peduncles (figure 2B) with slight increase in spination on distal segments, second segments each with area of calcification dorsally, medial plate still membranous.

Antennule. Upper ramus still with five, sometimes now with six articles, one or two additional pairs of aesthetascs; lower ramus usually completely three-segmented.

Antenna. First peduncular segment with prominent spine on lateral surface; scaphocerite larger and more acutely triangular, with prominent lateral spine; flagella each with eight or nine articles, setation as in previous stages.

Mandible (figure 2J). Medial margin smooth and sometimes slightly sinuous but also noticeably thickened, inner surface still with broad thick shelf in lower half; palp with 15-17 short marginal setae.

Maxillule. Coxal endite with additional simple and plumodenticulate setae; basial endite with additional spiniform, cuspidate setae marginally and plumose setae in submarginal row.

Maxilla. Lobes of coxal and basial endites all with additional setae; endopod unchanged; scaphognathite with 76-82 marginal plumose setae.

First maxilliped. Coxal and basial endites with increased setation; exopod now with 8-10 apical setae on distal segment. Second and third maxillipeds with endopod setation increased, exopods each with 10-12 apical setae.

Pereopods. Chelipeds distinctly asymmetrical, segments all with few additional spines; dactyls of ambulatory legs each still with five corneous spines on ventral margin and two calcareous spines on dorsal surface proximally; propodi, carpi and meri all with increased length and spination.

Abdomen (figure 6E, F). Symmetrically subtriangular; tergite of somite 1 completely fused with tergite of somite 2 (figure 6E), spines of second appreciably increased in number but not in size; tergites 3-5 (figure 6F) strongly flexed against thorax, lateral plates entirely separated from median plates, both with increased spination, marginal spines somewhat reduced in size.

Pleopods. Completely absent, sex indeterminate.

Telson. Subsemicircular, pair of small spines no longer terminal in position.

Abdominal plate development in supplemental stages (fourth crab stage $\mathrm{cl}=$ $3.6-4.2 \mathrm{~mm}, N=8$; fifth crab stage $\mathrm{cl}=4.5-5.6 \mathrm{~mm}, N=5$ ).

As previously indicated, five specimens that moulted to the fourth stage and exuviae of three individuals that successfully reached the fifth stage have been 
examined, together with five fifth crab stage individuals that either died or were killed at the termination of the nutritional study. No changes were observed in fused tergites 1 and 2 in these subsequent stages other than increases in size and some additional surface spines. The very preliminary development of accessory nodules in the marginal integument of tergites 3 and/or 4 such as that observed in the third stage in Lithodes santolla (Molina, 1782) (cf. McLaughlin et al., 2001) and L. aequispinus (Benedict, 1895) (cf. McLaughlin and Paul, 2002), was apparent at least on the right side of the abdomen in all but one of the fourth-stage specimens and exuviae. However, of those individuals where nodular development was limited to the right side, no asymmetry in the lateral plates could be detected. By the fifth crab stage (figure 8A, B), sexual dimorphism was clearly apparent, with quite small, but well-defined accessory marginal plates present on the right side in the three females and on both sides in the two males. Despite the absence of observable gonopores, the onset of female lateral plate asymmetry was unmistakable, particularly in tergite 5. There was no indication of pleopod development in these females.

\section{Results}

Although the initial zoeal stage in Paralomis is technically Zoea I (ZI), as reported by Konishi and Taishaku (1994), it is an atypical ZI. While the setation of the first and second maxillipeds corresponds to characteristic ZI setation, and the basial endite of the maxillule has two teeth, in all other respects, the first zoeal stage to hatch in this genus exhibits much more precocious morphology than typical Zoea I paguroid larvae. For example, the antennular endopod is already separated from the protopod, and the mandibular palp bud is already apparent. Additionally, the third maxilliped has both rami differentiated, and incipient or small pleopod buds are apparent on abdominal somites 2-5. Not only are all five pairs of pereopods present, with segments at last partially indicated, arthrobranchial gill buds also are moderately well developed at the bases of the chelipeds and ambulatory legs. Furthermore, but in contrast to the condition reported by earlier investigators, the eyes in our Paralomis first stage are stalked, not sessile.

There is no division of abdominal tergite 2 in Paralomis granulosa (figure 6B, D) early crab stages; there is only fusion of tergites 1 and 2 . Nonetheless, the types of segmental changes in tergites 3-5 between the megalopal and early crab stages in

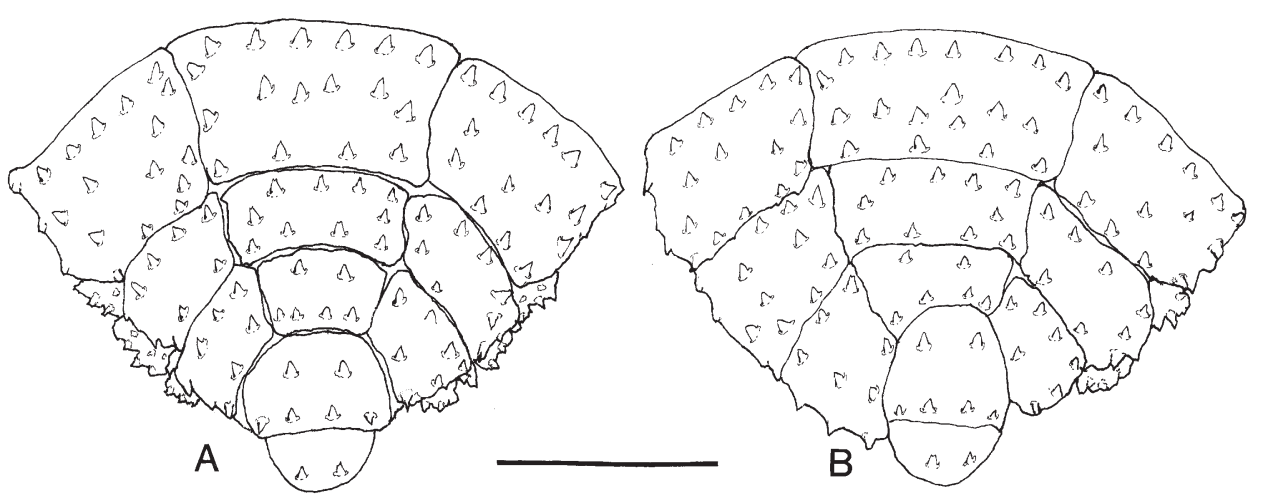

Fig. 8. Paralomis granulosa (Jacquinot, 1846). (A, B) Abdominal tergites 3-6 and telson (dorsal view). (A) Fifth crab stage male; (B) fifth crab stage female. Scale $=1.0 \mathrm{~mm}$. 
this species, i.e. division of megalopal tergites into median and lateral plates (figure 6B, D, F), are consistent with the findings of Crain and McLaughlin (2000a, $2000 \mathrm{~b}$ ) and McLaughlin and Lemaitre (2001) for other lithodids. However, comments by these authors regarding marginal plate development in tergites 3-5 were based on the assumption that similar sundering of the lateral plates, as suggested by marginal sutures in the first crab stages of Phyllolithodes and Acantholithodes (McLaughlin and Lemaitre, 2000: figures 2g, 4b), was equivalent to that observed in tergite 2 in these genera. McLaughlin et al. (2001) and McLaughlin and Paul (2002) have shown that not to be the case; marginal plate development, when it occurs in tergite 2 , is not homologous with 'marginal' plate development in tergites $3-5$. These latter authors have demonstrated that although there is initial, complete or partial sundering of the lateral plates of tergites 3-5 in species of Lithodes, by the fourth stage, total refusion has occurred. The 'marginal' plates that develop do not represent a division of the lateral plates into lateral and marginal elements as they do in tergite 2 in some genera. Rather, the so-called 'marginal' plates of tergites $3-5$ result from accessory nodular calcification in the marginal integument beginning at the third crab stage in the two species studies. During the first three crab stages of $P$. granulosa there is no indication of sundering of the lateral plates, nor of any accessory nodular calcification. The first evidence of accessory marginal plate development occurs at the fourth crab stage in Paralomis granulosa, and appears to proceed rather rapidly in stage 5 (figure $8 \mathrm{~A}, \mathrm{~B}$ ).

\section{Discussion}

In a recent review of the Lithodidae from the Atlantic Ocean, Macpherson (1988) defined the genus Paralomis as having the second abdominal segment formed by a single plate. The third to fifth segments (tergites) were said to exhibit clearly differentiated, well-calcified plates without nodules or membranous areas. A median plate, a pair of lateral plates and a pair of marginal plates were present on each of these segments, with the marginal and lateral plates of the third segment, and rarely also the fourth, sometimes fused. Marginal plates on any segment might also be subdivided. Macpherson did not mention the first segment, but it is clear from development in P. granulosa juveniles of stages 3-5 that the tergites of the first and second somites fuse to present a single 'second' segment.

Macpherson's (1988) reference to 'well calcified plates without nodules or membranous areas' reflects the acceptance, at that time, of Bouvier's (1894a, 1894b, $1895,1897)$ hypothesis, which called for the gradual transformation of an almost exclusively membranous hermit crab abdomen into a highly complex series of partially to fully calcified tergites in the lithodids. In Bouvier's evolutionary framework, this almost completely membranous integument was first invaded by calcified nodules, and ultimately, through the fusion of these nodules, solid plates were formed such as those seen in Paralomis. However, Crain and McLaughlin (2000a) demonstrated that in the first and second crab stages of Lopholithodes mandtii the initially, completely calcified tergites of the megalopa developed sutures that divided the third to the fifth tergites into separate median and lateral plates. As the divisionary process proceeded, a certain amount of decalcification occurred, resulting in the separation of the median and lateral plates by membranous areas. Similar, albeit less dramatic, results were shown by these authors to occur in a second lithodid genus (Crain and McLaughlin, 2000b). McLaughlin and Lemaitre (2001) subsequently examined megalopal and first crab stages from six additional lithodid 
genera. These authors expressed the belief that their evidence showed conclusively that adult abdominal plate structures were formed by decalcification and/or sundering of the megalopal tergites to varying degrees, not by the formation and subsequent fusion of calcified nodules. Our findings of plate development in Paralomis support their conclusion as far as median and lateral plate formation is concerned. Similarly, our observations on tergite development in P. granulosa and Lithodes santolla (McLaughlin et al., 2001) negate the hypothesis of secondary abdominal plate calcification in these particular genera as proposed by Richter and Scholtz (1994). Macpherson (1988) observed the absence of the marginal plates of the third tergite sometimes, and also the fourth rarely, and suggested that in some instances the marginal and lateral plates fused in Paralomis granulosa. As is evidenced by the development of accessory marginal plates by the fifth crab stage in our specimens, a more accurate interpretation would be that accessory marginal plates occasionally may not always develop on tergite 3 , and less frequently, also on tergite 4.

Crain and McLaughlin (2000b) discussed the developmental variability in morphological characters displayed among genera of the Lithodidae. This variability is particularly true of pleopod development and loss. Contrary to the statement by these authors that pleopods develop on the second to fifth abdominal somites only in the megalopal stage in species of Paralomis, biramous pleopod buds were developed in first-stage zoeas reared by Campodonico and Guzmán (1981), but only uniramous buds were present both in our first-stage specimens and in those of Paralomis hystrix reared by Konishi and Taishaku (1994). McLaughlin et al. (2001) discussed the apparent errors in zoeal stage identification by MacDonald et al. (1957) and Haynes (1982) for Lithodes species, which led to inaccurate pleopod staging by these authors. Thus it would appear that these four pairs of pleopods first develop in second-stage zoeas in Lithodes (Campodonico, 1971; Anger, 1996, McLaughlin et al., 2001), Cryptolithodes (Hart, 1965; Kim and Hong, 2000) and Dermaturus (Kurata, 1956), in the second- to fourth-stage zoeas in Paralithodes (e.g. Kurata, 1960; Makarov, 1966; Hoffman, 1968), in the third stage in Lopholithodes (Crain and McLaughlin, 2000a) and Placetron (Crain and McLaughlin, 2000b), and in the third or fourth stage in Hapalogaster (Miller and Coffin, 1961; Konishi, 1986). No pleopods develop on the first abdominal somite in any lithodid species during larval and early juveniles stages.

Pleopod loss has only recently been addressed. Sandberg and McLaughlin (1998) reported that pleopods were entirely absent in juvenile specimens of Lithodes maja (Linnaeus, 1758) with carapace lengths of less than $6.0 \mathrm{~mm}$. Crain and McLaughlin (2000a) noted reduction of pleopods in the first crab stage of Lopholithodes mandtii, with complete loss almost universal in their second-stage specimens. Pleopods were completely absent in four of the five first crab stage specimens of Paralomis granulosa that we examined. The pleopods of the fifth specimen were markedly reduced (figure 6C). No evidence of pleopods was found in any of our second to fifth crab stage specimens of $P$. granulosa. In contrast, paired, but reduced pleopods in first crab stage specimens of Paralithodes brevipes (H. Milne Edwards and Lucas, 1841) were reported by Kurata (1956), and by Hart (1965) for Cryptolithodes typicus Brandt, 1848. Crain and McLaughlin (2000b) found reduction in the pleopods of Placetron wosnessenskii Schalfeew, 1892, during the first crab stage, as did Miller and Coffin (1961) for Hapalogaster mertensii Brandt, 1850. No subsequent stages of these species were available to the investigators. McLaughlin et al. (2001) found 
pleopods present, but reduced during the first crab stage of Lithodes santolla and vestigial or absent by the second stage, while McLaughlin and Paul (2002) found pleopod loss occurring almost uniformly during the first crab stage of L. aequispinus. Given these findings, it is highly probable that complete pleopod loss occurs in both sexes during the early juveniles stages, but varies within and among species. It clearly is not an exclusively moult or stage-controlled phenomenon. Pleopods remain completely absent in male lithodids but, as reported by Sandberg and McLaughlin (1998) and McLaughlin and Paul (2002), redevelop on the left side in females, presumably for egg-carrying purposes.

\section{Acknowledgements}

This is a scientific contribution from the Shannon Point Marine Center, Western Washington University, and a contribution to research project ARG 99/002 funded by the International Bureaus of the DLR (Bonn, Germany) and the Secretaria de Tecnologia, Ciencia e Innovación Tecnológic (Argentina). Special thanks are due to the crew members of 'Pesquera del Beagle' S.A. (fishing company, Ushuaia, Argentina) for their valuable support in fishing and maintaining the king crabs. We are grateful also to F. Tapella and A. Chicczini for their assistance in the field, and to I. Serendero, U. Warnat and B. Klein who helped in the transport of the live material on-board the RV Polarstern.

\section{References}

Anger, K., 1996, Physiological and biochemical changes during lecithotrophic larval development and early juvenile growth in the northern stone crab, Lithodes maja (Decapoda: Anomura), Marine Biology, 126, 283-296.

Balss, H., 1911, Neue Paguriden aus den Ausbeuten der deutschen Tiefsee-Expedition 'Valdivia' und der japanischen Expedition Prof. Dofleins, Zoologischer Anzeiger, 38, 1-9.

BENEDICT, J.E., 1895, Descriptions of new genera and species of crabs of the family Lithodidae with notes on the young of Lithodes camtschaticus and Lithodes brevipes, Proceedings of the United States National Museum, 17, 479-488.

Bouvier, E.-L., 1894a, Sur les caractères et l'évolution des Lomisinés, nouveau groupe de crustacés anomures, Compte Rendu Sommaire des Séances de la Société Philomathique de Paris, 118, 1353-1355.

Bouvier, E.-L., 1894b, Sur la transformation des Paguriens en crabes anomures de la sousfamille des Lithodinés, Compte Rendu Sommaire des Séances de la Société Philomathique de Paris, 119, 350-352.

Bouvier, E.-L., 1895, Recherches sur les affinités des Lithodes \& des Lomis avec les Pagurides, Annales des Sciences Naturelles, Zoologie et Paléontologie, 18(7), 157-213.

Bouvier, E.-L., 1897, La transformation des Bernards l'Ermite en Lithodes, Naturaliste, (2) 19(230), 41-43.

BRAndT, J.F., 1848, Die Gattung Lithodes Latreille nebst vier neuen ihr verwandten von Wosnessenski entdeckten, als Typen einer besondern Unterabtheilung (Tribus Lithodea) der Edward'schen Anomuren, Bulletin de la Classe physico-mathématique de l'Académie Impériale des Sciences de Saint Pétersbourg, 7(11), 171-176.

BRANDT, J.F., 1850, Bericht über die für die Reisebeschreibung des Herrn von Middendorff von J.F. Brandt bearbeiteten Krebsthiere aus den Abtheilungen der Brachyuren (Krabben), Anomuren und Makrouren (Krebse), Bulletin de la Classe physicomathématique de l'Académie Impériale des Sciences de Saint Pétersbourg, 8(13), 234-238.

CAmpodonico, G.I., 1971, Desarrollo larval de la centolla Lithodes antarctica Jacquinot en condiciones de laboratorio (Crustacea Decapoda, Anomura: Lithodidae), Anales del Instituto de la Patagonia, 2, 181-190.

Campodonico, I. and Guzmán, L., 1981, Larval development of Paralomis granulosa (Jacquinot) under laboratory conditions (Decapoda, Anomura, Lithodidae), Crustaceana, 40, 272-285. 
CraIN, J.A., 1999, Functional morphology of prey ingestion by Placetron wosnessenskii Schalfeew zoeae (Crustacea: Anomura: Lithodidae), Biological Bulletin, 197, 207-218.

Crain, J.A. and McLaughlin, P.A., 2000a, Larval and early juvenile development in the Lithodidae (Decapoda: Anomura: Paguroidea) reared under laboratory conditions. 1. Subfamily Lithodinae: Lopholithodes mandtii Brandt, 1848, Invertebrate Reproduction and Development, 37, 43-59.

Crain, J.A. and McLaughlin, P.A., 2000b, Larval and early juvenile development in the Lithodidae (Decapoda: Anomura: Paguroidea) reared under laboratory conditions. 2. Hapalogastrinae: Placetron wosnessenskii Schalfeew, 1892, with notes on comparative development within the subfamilies of the Lithodidae, Invertebrate Reproduction and Development, 37, 113-127.

Fincham, A.A., 1992, Ontogeny of anomuran eyes, in A.A. Fincham and P.S. Rainbow, eds. Aspects of decapod crustacean biology, Symposium of the Zoological Society of London (1988), 59, 123-155.

HaAn, W. De, 1833-1850, Crustacea, in P.F. von Siebold, Fauna Japonica, sive Descriptio animalium, quae in itinere per Japoniam, jussu et auspiciis superiorum, qui summum in India Batava imperium tenent, suscepto, annis 1823-1830 collegit, notis, observationibus et adumbrationibus illustravit P.F. de Siebold. Conjunctis studiis C.J. Temminck et $H$. Schlegel pro Vertebratis atque $W$. de Haan pro Invertebratis elaborata Regis aupicus edita. (Leiden: Lugduni- Batavorum, Decas), pp. i-xxi, vii-xvii, ix-xvi +1-243.

HART, J.F.L., 1965, Life history and larval development of Cryptolithodes typicus Brandt (Decapoda, Anomura) from British Columbia, Crustaceana, 8, 255-276.

Hayashi, K. and Yanagisawa, F., 1985, Zoeae of Paralomis japonicus Balss (Crustacea, Decapoda, Lithodidae), Nankiseibutsu, 27, 23-26 [in Japanese with English summary].

HAYNES, E., 1982, Description of larvae of the golden king crab, Lithodes aequispina, reared in the laboratory, Fishery Bulletin, 80, 305-313.

Hoffman, E.G., 1968, Description of laboratory-reared larvae of Paralithodes platypus (Decapoda, Anomura, Lithodidae), Journal of the Fisheries Research Board of Canada, 25, 439-455.

Hombron, J.B. and JACQuinot, H., 1846 [July], Atlas d'Histoire Naturelle Zoologie par MM. Hombron et Jacquinot, chirurgiens de l'expédition, in Voyage au pole sud et dans l'Océanie sur les corvettes l'Astrolabe et la Zélée exécuté par ordre du roi pendant les années 1837-1838-1839-1840 sous le commandement de M. Dumont-D’Urville capitaine de vaisseau publié sous les auspices du département de la marine et sous la direction superieure de M. Jacquinot, capitaine de Vaisseau, commandant de la Zélée. Dix-Huitième Livraison. Oiseaux pl. 21; Crustacés pls 3, 4; Insectes coléoptères pls. 16, 17 (Paris: Gide et $\mathrm{Cie}$ ).

KafFenberger, A., 2001, Einfluss der Nahrung auf den Stoffbestand der Larvenstadien von Paralomis granulosa und Lithodes santolla (Decapoda: Anomura: Lithodidae), Diplomarbeit, Universtät Heidelberg, 86 pp. [unpublished].

KIm, M.H. and Hong, S.Y., 2000, Larval development of Cryptolithodes expansus Miers (Decapoda: Anomura: Lithodidae) reared in the laboratory, Proceedings of the Biological Society of Washington, 113, 54-65.

Konishi, K., 1986, Larval development of the stone crab, Hapalogaster dentata (DeHaan, 1844) (Crustacea: Anomura: Lithodidae) reared in the laboratory, Journal of the Faculty of Science, Hokkaido University, (4) Zoology, 24, 155-172.

Konishi, K. and Taishaku, H., 1994, Larval development in Paralomis hystrix (De Haan, 1846) (Crustacea, Anomura, Lithodidae) under laboratory conditions, Bulletin of the National Research Institute for Aquaculture, 23, 43-54.

Kurata, H., 1956, The larval stages of Paralithodes brevipes (Decapoda, Anomura), Bulletin of the Hokkaido Regional Fisheries Research Laboratory, 14, 25-34.

Kurata, H., 1960, Last stage zoea of Paralithodes with intermediate form between normal last stage zoea and glaucothoe, Bulletin of the Hokkaido Regional Fisheries Research Laboratory, 22, 49-56.

Linnaeus, C., 1758, Systema naturae per regna tria naturae, secundum classes, ordines, genera, species, cum characteribus, differentiis, synonymis locis, ed. 10: 1: i-ii, 1-824. (Holmiae).

MacDonald, J.D., Pike, R.B. and Williamson, D.I. 1957, Larvae of the British species of Diogenes, Pagurus, Anapagurus and Lithodes (Crustacea, Decapoda), Proceedings of the Zoological Society of London, 128, 209-257. 
MacPherson, E., 1988, Revision of the family Lithodidae Samouelle, 1819 (Crustacea, Decapoda, Anomura) in the Atlantic Ocean, Monografias de Zoología Marina, 2, 9-153.

MAKAROV, R.R., 1966, Lichinki krevetok, rakovotshel'nikov i krabov zapadnokamchatskogo shel'fa i ikh raspredelenie. [Larvae of the shrimps and crabs of the west Kamchatkan shelf and their distribution] (Moscow: Akademia Nauk SSSR. Izdatel'ctvo Nauka), pp. 1-163 [in Russian].

McLaughlin, P.A. and Lemaitre, R., 2001, Aspects of evolution in the anomuran superfamily Paguroidea: one larval prospective, Invertebrate Reproduction and Development, 38, 159-169.

McLaughlin, P.A. and Paul, J.M., 2002, Abdominal tergite and pleopod changes in Lithodes aequispinus Benedict, 1895 (Decapoda: Anomura: Lithodidae) from megalopa to adolescent, Proceedings of the Biological Society of Washington, 115, 138-147.

Mclaughlin, P.A., Anger, K., Kaffenberger, A. and Lovrich, G.A., 2001, Megalopal and early juvenile development in Lithodes santolla (Molina) (Decapoda: Anomura: Paguroidea: Lithodidae), with notes on zoeal variations, Invertebrate Reproduction and Development, 40, 53-67.

Miller, P.E. and Coffin, H.G., 1961, A laboratory study of the developmental stages of Hapalogaster Mertensii [sic] (Brandt), (Crustacea, Decapoda), Walla Walla College and Biological Station, 30, 1-20.

Milne Edwards, H. and Lucas, H., 1841, Déscription des Crustacés nouveau ou peu connu, Archives du Muséum d'Histoire Naturelle, Paris, 2, 463-483.

Molina, G.I., 1782, Saggio sulla storia naturale del Chili (Bologna), pp. 1-367

Powar, C.B., 1969, Musculature of the eyestalk in Crustacea, Acta Zoologica, 50, 127-141.

Richter, S. and Scholtz, G., 1994, Morphological evidence for a hermit crab ancestry of lithodids (Crustacea, Decapoda, Anomala, Paguroidea), Zoologischer Anziger, 223(5/6), 187-219.

Sandberg, L. and Mclaughlin, P.A., 1998, Crustacea, Decapoda, Paguridae, in Marine Invertebrates of Scandinavia, Vol. 10 (Oslo: Universitetsforlaget), pp. 1-113.

SchalfeEw, P., 1892, Carcinologische Bemerkungen aus dem Zoologischen Museum der Kaiserlichen Akademie der Wissenschaften, Bulletin de l'Académie Impériale des Sciences de Saint Pétersbourg, 35, 331-342. 